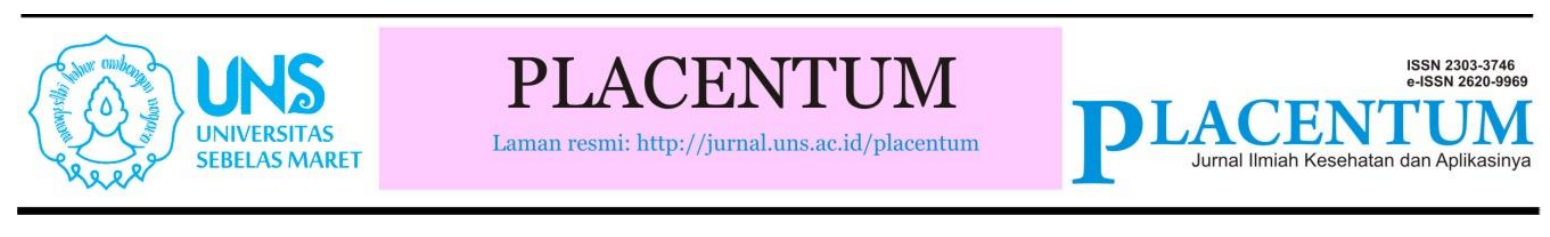

\title{
ANALISIS IMPLEMENTASI CONTINUITY OF CARE (COC) DI PROGRAM STUDI D III KEBIDANAN UNS
}

\section{Analysis Of Continuity Of Care (COC) Implementation In Study Program D III Midwifery UNS}

\author{
Hardiningsih $^{1)}$, Fresthy Astrika Yunita ${ }^{2)}$, Agus Eka Nurma Yuneta ${ }^{3)}$ \\ ${ }^{*}$ Prodi D III Kebidanan, SV, Universitas Sebelas Maret, Jl. Ir. Sutami 36A, Kentingan Surakarta 57126 telp. \\ (0271) 662622 \\ E-mail : $\underline{\text { mrshardiningsih @ gmail.com }}$
}

\begin{abstract}
ABSTRAK
Latar Belakang: Continuity of Care (CoC) merupakan layanan kebidanan melalui model pelayanan berkelanjutan pada perempuan sepanjang masa kehamilan, persalinan, nifas dan keluarga berencana. Bidan sebagai subsistem sumber daya manusia menjadi salah satu ujung tombak yang berperan langsung pada percepatan penurunan angka kematian ibu dan atau angka kematian bayi. Tujuan Penelitian : menganalisis impelementasi metode Continuity of Care (CoC) di Program Studi D III Kebidanan UNS.

Subjek dan Metode: Desain penelitian kualitatif. Lokasi penelitian di Prodi D III Kebidanan UNS mulai bulan April 2019. Informan terdiri dari dosen koordinator CoC, pembimbing institusi, pembimbing lahan dan mahasiswa serta klien. Pengumpulan data dilakukan melalui wawancara, kajian dokumen dan observasi partisipasi. Analisis data menggunakan model interaktif

Hasil penelitian: Implementasi metode CoC pada LTA ini mahasiswa dapat menunjukkan kompetensinya kepada klien melalui pelaksanaan asuhan kebidanan. Klien merasa puas dengan pendampingan yang dilakukan oleh mahasiswa. Pelaksanaan LTA dengan metode CoC ini memberikan dampak yang positif bagi institusi pendidikan, klien serta untuk mahasiswa dapat memberikan pengalaman nyata tentang asuhan kebidanan.

Kesimpulan: Implementasi LTA dengan metode CoC di Prodi D III Kebidanan sudah terlaksana denga baik.
\end{abstract}

Kata Kunci : continuity of care, kebidanan, pelayanan 


\begin{abstract}
Background: Continuity of Care $(\mathrm{CoC})$ is one of midwifery long term services in women throughout their period of pregnancy, giving birth, puerperal and family's planning. Because all women have risk of complications that can lead to maternal or infant death at each of the stage of life. Midwife as a subsystem of human resources become one of an important thing which play a direct role in accelerating the decline in maternal mortality rates and or infant mortality rates. The aim of research is to analyze the implementation of Continuity of Care (CoC) methods in the UNS D III Midwifery study program.

Methods: We are using qualitative research design. The location of this research has been held in UNS Midwifery study program, from April 2019. The informant consist of the coordinator lecturer of $\mathrm{CoC}$, institution supervisor, land supervisor, and students also clients. To collect the data, we chose a deep interview, document review, and participant observation. To analyze the data, we are using interactive models.

Results: The implementation process of LTA with CoC method, students can show their competence to a patient through the implementation of midwifery care. Patient feeling satisfied with the assistance that provided by the students. This implementation with CoC methods make an positive impact for the education institution, patient also for the students can give a real experience about midwifery care.
\end{abstract}

Conclusion: The implementation of LTA with CoC method in D III Midwifery study program has been well implemented.

Keywords: Continuity of care, midwifery, service 


\section{PENDAHULUAN}

Bidan merupakan profesi kunci dalam pelayanan terhadap perempuan selama daur kehidupan dan bidan mempunyai otoritas besar terhadap kesejahteraan kesehatan perempuan. Sehingga profesionalisme bidan merupakan elemen penting dalam pemberdayaan perempuan. Seiring semakin berkembangnya ilmu pengetahuan dan teknologi, berdampak pada meningkatnya kebutuhan masyarakat akan mutu pelayanan kesehatan khususnya pelayanan kebidanan dengan indikator keberhasilan menurunnya Angka Kematian Ibu (AKI) dan atau Angka Kematian Bayi (AKB) secara bermakna. Mutu pelayanan kebidanan identik dengan bidan yang kompeten. Tenaga bidan yang bermutu, memiliki kemampuan komprehensif dan professional yang hanya dapat dihasilkan melalui institusi penyelenggara pendidikan bidan yang berkualitas ${ }^{[1]}$.

Standar pendidikan bidan dari International Confederation of Midwifery (ICM), menyatakan bahwa filosofi pendidikan bidan harus konsisten dengan filosofi asuhan kebidanan. Filosofi asuhan kebidanan adalah meyakini bahwa proses reproduksi perempuan merupakan proses alamiah dan normal yang dialami oleh setiap perempuan. Bidan dalam memberikan asuhan harus bermitra dengan perempuan, memberi kewenangan pada perempuan, asuhan secara individual, asuhan secara terus menerus dan berkelanjutan

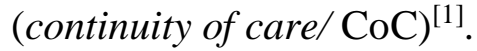

Program Studi D III Kebidanan UNS dalam penyusunan Laporan Tugas Akhir (LTA) menggunakan metode $\mathrm{CoC}$ yaitu mahasiswa mulai semester $\mathrm{V}$ menyusun laporan kasus yang diambil dari kasus asuhan kebidanan berkelanjutan (CoC) kepada ibu dan bayi yang meliputi kehamilan, persalinan, bayi baru lahir, nifas dan keluarga berencana. Penerapan metode $\mathrm{CoC}$ ini bertujuan membekali lulusan agar menjadi bidan yang mampu bekerja berdasarkan filosofi asuhan kebidanan.
Penelitian sebelumnya menunjukkan bahwa model asuhan secara terus menerus dan berkelanjutan (Continuity of Care/ $\mathrm{CoC}$ ) merupakan sebuah contoh praktik terbaik, yang memungkinkan siswa bidan mengembangkan ketrampilan bekerja secara kemitraan dan lebih percaya diri saat mereka mengalami model asuhan dengan mengikuti perempuan selama hamil-bersalin-nifas ${ }^{[2]}$.

Berdasarkan latar belakang diatas maka peneliti tertarik untuk meneliti tentang analisis implementasi metode COC sebagai model penyusunan LTA mahasiswa di Prodi D III Kebidanan FK UNS.

\section{SUBJEK DAN METODE}

Desain penelitian ini merupakan penelitian kualitatif berupa embedded case study (studi kasus) yang artinya penelitian ini difokuskan pad satu fenomena saja yang dipilih yaitu implementasi metode COC. Penelitian ini dilaksanakan di Prodi D III Kebidanan FK UNS. Waktu penelitian direncanakan selama 7 (Tujuh) bulan mulai April sampai dengan November 2019.

Populasi penelitian kualitatif berupa situasi sosial yang terdiri dari tempat (place), pelaku (actor) dan aktivitas (activity) yang berinteraksi secara sinergis. Teknik pengambilan sampel dengan mengunakan purposive sampling yaitu teknik pengambilan sampel sumber data dengan menggunakan pertimbangan tertentu, misalnya orang yang dianggap paling tahu tentang apa yang kita harapkan atau dia sebagai penguasa sehingga memudahkan peneliti menjelajahi objek/ situasi sosial yang diteliti.

Teknik pengumpulan data dilakukan dengan cara wawancara mendalam kepada informan yaitu para stakeholders meliputi pimpinan program studi, dosen koordinator COC, dosen pembimbing laporan tugas akhir, bidan puskesmas selaku pembimbing 
lahan laporan tugas akhir dan mahasiswa sendiri serta klien sebagai subjek COC; melakukan kajian dokumen yaitu mengumpulkan data yang bersumber dari dokumen dan arsip terkait dengan pelaksanaan kegiatan penyusunan laporan tugas akhir dengan metode COC; melakukan observasi partisipasi yaitu peneliti ikut berpartisipasi dalam pelaksanaan di setiap tahap dari metode COC. Setelah data terkumpul maka dilakukan uji kepercayaan data melalui triangulasi, perpanjangan keikutsertaan dan member check.

Analisis penelitian kualitatif bersifat interaktif yang prosesnya dimulai dengan menelaah seluruh data yang tersedia dari berbagai sumber yaitu wawancara, pengamatan

Prodi D III Kebidanan FK UNS merupakan institusi pendidikan yang mendidik mahasiswa menjadi bidan yang professional, salah satunya dengan menerapkan model Continuity of Care (CoC) pada penyusunan laporan tugas akhir (LTA) mahasiswa. Model CoC ini sudah berjalan 3 tahun sejak tahun 2017, dimana mahasiswa akan mendampingi satu klien kemudian akan dilakukan asuhan yang menyeluruh dari hamil, bersalin, masa nifas, bayi baru lahir sampai dengan keluarga berencana (KB). Pelaksanaan penyusunan laporan tugas akhir ini tidak disediakan waktu khusus tetapi dilakukan terintegrasi bersamasama dengan pelaksanaan proses belajar mengajar di semester V (lima). Namun, LTA ini mempunyai kedudukan sebagai mata kuliah pada semester VI (enam) yang dilakukan secara terintegrasi sebagai bagian dari ujian akhir program untuk menyelesaikan pendidikan.

Pembimbing LTA dengan metode $\mathrm{CoC}$ ini terdiri dari dua orang pembimbing. Pembimbing I (utama LTA) adalah dosen yang berlatar belakang bidan dengan pendidikan minimal S2 Kesehatan, dan menguasai tentang bidang materi/ permasalahan yang dibahas oleh mahasiswa. Sedangkan pembim- yang tertulis dalam catatan lapangan, dokumen resmi dan lain-lain. Setelah dipelajari dan ditelaah maka langkah selanjutnya mengadakan reduksi data yang dilakukan dengan membuat abstraksi. Abstraksi merupakan usaha membuat rangkuman inti. Tahap terakhir dari analisis ini adalah penarikan kesimpulan dari penelitian.

\section{HASIL}

$\overline{\text { Penelitian tentang model CoC dalam pelaksa- }}$ naan LTA telah dilakukan dan hasil yang didapat antara lain :

\section{Pelaksanaan LTA dengan model CoC di Prodi D III Kebidanan FK UNS}

bing II (pendamping) adalah bidan dengan latar belakang pendidikan minimal D IV Kebidanan yang mempunyai wilayah kerja di puskesmas dan menguasai metode serta teknik penyusunan LTA . Berdasarkan hasil wawancara dengan dosen koordinator CoC prodi D III Kebidanan FK UNS serta studi dokumen yang dilakukan dalam penelitian ini untuk pembimbing I berjumlah 9 orang dan pembimbing II berjumlah 14 orang yang semuanya memenuhi syarat yang ditentukan oleh Prodi D III Kebidanan FK UNS. Pembimbing II tersebut merupakan bidan yang berkerja di puskesmas di wilayah Dinas Kesehatan Kota Surakarta.

Dosen koordinator CoC Prodi D III Kebidanan juga menyampaikan bahwa sebelum pelaksanaan pembimbingan, program studi melakukan rapat koordinasi antara pembimbing I, pembimbing II dan pengelola program studi terkait sosialisasi pelaksanaan LTA dengan model $\mathrm{CoC}$ ini yang harapannya nantinya dapat berjalan dengan baik dan lancar. Pengumpulan data dengan wawancara juga dilakukan kepada pembimbing II, mereka memberikan masukan bahwa dengan adanya sosialisasi pelaksanaan LTA dengan metode $\mathrm{CoC}$ sudah sangat baik, akan tetapi per- 
lu ditambahkan persamaan persepsi dengan pembimbing I terkait materi,teknik dan isi dari LTA dengan metode $\mathrm{CoC}$ ini, sehingga diharapkan memiliki kemampuan yang sama dalam membimbing mahasiswa dalam penyusunan LTA karena masih terdapat perbedaan pendapat antara pembimbing I dan pembimbing II. Pembimbing II sangat tertarik dengan model pembelajaran ini karena akan memberikan pengalaman baru bagi mahasiswa. Selain rapat sosialisasi dengan pembimbing, dosen koordinator $\mathrm{CoC}$ prodi D III Kebidanan FK UNS juga mengatakan bahwa sosialisasi (pembekalan) juga disampaikan kepada mahasiswa

2. Pengalaman mahasiswa

Kegiatan LTA dengan model CoC meliputi penyusunan proposal dalam bentuk laporan pendahuluan dan pencarian subjek (klien) yang akan diberikan asuhan kebidanan berkelanjutan (continuity of care) yaitu ibu hamil dengan umur kehamilan minimal 32 minggu. Selanjutnya mahasiswa mulai melaksanakan asuhan kebidanan berkelanjutan $(\mathrm{CoC})$ tersebut kepada klien yang telah diperoleh yaitu kepada ibu dan bayi yang meliputi kehamilan, persalinan, bayi baru lahir, nifas dan KB dengan pendekatan manajemen kebidanan serta menyusun laporan hasil asuhan kebidanan kepada ibu hamil, bersalin, bayi baru lahir, nifas dan KB.

Mahasiswa pada semester $\mathrm{V}$ sudah dapat mulai melakukan penyusunan LTA dengan metode $\mathrm{CoC}$ ini, akan tetapi pada hasil wawancara yang dilakukan kepada mahasiswa didapatkan mereka kesulitan memulai pelaksanaan CoC dalam penyusunan LTA karena mahasiswa masih mengikuti kegiatan praktik klinik kebidanan yang ada di semester $\mathrm{V}$ dikarenakan lokasi praktik klinik yang jauh dari kampus sehingga menghambat dalam penyusunan proposal, konsultasi dengan pembimbing, pencarian subjek (klien) CoC serta mendampingi klien.
Implementasi selanjutnya yaitu melakukan pemantauan asuhan kepada subjek yang dilaksanakan sejak kehamilan, persalinan, bayi baru lahir, nifas dan KB dalam kurun waktu selama 4 bulan, namun dalam kenyataan pelaksanaannya dari hasil wawancara dan studi observasi menunjukkan bahwa lama pelaksanaan asuhan berkisar antara 3-6 bulan, karena ada beberapa mahasiswa yang subjek asuhannya melahirkan tidak sesuai dengan hari perkiraan lahir, selain itu ada mahasiswa mengatakan bahwa dirinya sempat berganti subjek asuhan karena subjek asuhan tidak berkenan untuk mendapatkan asuhan berikutnya dan bayi yang dikandung subjek asuhan meninggal didalam rahim. Frekuensi pemberian asuhan dilakukan sebanyak 11 kali dengan rincian 2 kali saat subjek (ibu) hamil trimester III, 1 kali saat bersalin, 3 kali saat nifas, 3 kali saat neonatus serta 2 kali saat KB. Validasi proposal dilaksanakan di lahan praktik saat pemberian asuhan kehamilan yang dihadiri oleh mahasiswa, klien dan kedua pembimbing, dalam implementasinya, melalui studi dokumen dan observasi langsung saat validasi proposal didapatkan mahasiswa dapat melakukan asuhan kehamilan sesuai dengan teori dan masalah yang dialami klien serta menunjukkan kompetensinya.

Asuhan persalinan diharapkan mahasiswa dapat ikut berpartisipasi, akan tetapi dalam implementasinya berdasarkan pengumpulan data melalui wawancara dengan mahasiswa dan pembimbing terdapat mahasiswa yang tidak bisa berpartisipasi langsung dalam melakukan asuhan persalinan kepada klien. Hal ini dikarenakan antara lain klien ingin melahirkan di rumah sakit/ klinik atau klien mengalami persalinan patologis sehingga harus bersalin di rumah sakit serta mahasiswa sedang praktik di luar kota sehingga pada saat proses persalinan mahasiswa tidak bisa atau terlambat mengikuti. Mahasiswa 
masih dapat melanjutkan asuhan setelah persalinan dan untuk dokumentasi asuhan persalinan mahasiswa dapat melihat dari catatan medis klien atau melakukan wawancara dengan bidan atau dokter yang bertugas saat persalinan tersebut. Sedangkan untuk implementasi asuhan nifas, berdasarkan wawancara dengan mahasiswa dan pembimbing II telah dilaksanakan tiga kali dan mahasiswa selalu melakukan pendampingan kepada klien dengan mendapatkan pengawasan dari pembimbing II secara langsung atau dengan bidan atau dokter lain, hal ini termasuk juga untuk asuhan bayi baru lahir dan KB.

Kunjungan nifas dan kunjungan neonatal yang ketiga dilakukan oleh mahasiswa dihadapan pembimbing I dan pembimbing II, ini sebagai syarat untuk mahasiswa mengikuti seminar hasil LTA. Ketrampilan mahasiswa dalam melakukan asuhan nifas dan BBL sudah baik dan kompeten, pembimbing menyampaikan bahwa ketrampilan mahasiswa sudah sesuai teori dan dapat memberikan informasi kepada klien sesuai dengan kondisinya misalnya seperti rencana $\mathrm{KB}$ yang akan digunakan, informasi tentang menyusui, informasi tentang tanda bahaya ibu nifas dan BBL.

\section{Klien}

Klien menyampaikan senang dan puas dengan asuhan yang telah dilakukan oleh mahasiswa. Klien mendapatkan asuhan dan pendampingan dari mahasiswa sejak kehamilan, persalinan, nifas, bayi baru lahir dan KB. Selain asuhan yang diberikan oleh mahasiswa, klien merasa terbantu dengan adanya pendampingan dari mahasiswa, msalnya jika ada keluhan dalam kehamilan, masalah menyusui atau masalah lain klien dapat menghubungi mahasiswa dan mahasiswa memberikan respon yang baik. Terkait pelaksanaannya, asuhan berkelanjutan $(\mathrm{CoC})$ ini yang terdiri dari asuhan kehamilan, persalinan, nifas, BBL dan KB dilakukan oleh mahasiswa de- ngan persetujuan klien untuk dapat melakukan pemeriksaan fisik pada ibu dan bayinya atau asuhan yang lainnya sesuai masalah klien. Beberapa hal disampaikan oleh mahasiswa bahwa ada prosedur yang klien kurang berkenan untuk dilakukan, misalnya pemeriksaan genitalia pada saat hamil dan pemeriksaan luka jahitan atau jalan lahir pada saat nifas. Akan tetapi, mahasiswa tetap dapat melakukan pengumpulan data melalui anamnesa ke klien.

4. Keberlanjutan model CoC sebagai model pembelajaran lainnya di Prodi D III Kebidanan FK UNS

Wawancara juga dilakukan kepada pembimbing I didapatkan hasil bahwa pelaksanaan metode CoC dalam penyusunan LTA ini sudah berjalan sesuai buku panduan. Mereka berpendapat bahwa Metode $\mathrm{CoC}$ ini sebaiknya juga diterapkan dalam pembelajaran praktik klinik sehingga mahasiswa nantinya terbiasa melakukan asuhan yang berkelanjutan dan melakukan pendampingan pada ibu (klien) sejak kehamilan sampai dengan KB serta pada bayinya. Pembimbing II yang merupakan pembimbing dari lahan juga menyampaikan bahwa mahasiswa Prodi D III Kebidanan UNS perlu diberikan pengalaman yang banyak dengan model $\mathrm{CoC}$ sehingga nantinya di dunia kerja mahasiswa ini dapat menerapkan model tersebut dalam memberikan asuhan.

\section{PEMBAHASAN}

Hasil penelitian menunjukkan bahwa model CoC yang diterapkan pada LTA di Prodi D III Kebidanan Fakultas FK UNS yaitu mahasiswa mendampingi satu klien kemudian akan dilakukan asuhan yang menyeluruh dari hamil, bersalin, masa nifas, bayi baru lahir sampai dengan keluarga berencana (KB). Model CoC ini sesuai dengan penelitian yang dilakukan oleh Homer et al (2014) yang menjelaskan tentang $\mathrm{CoC}$ dalam kebidanan ada- 
lah serangkaian kegiatan pelayanan yang berkelanjutan dan menyeluruh mulai dari kehamilan, persalinan, nifas, pelayanan bayi baru lahir serta pelayanan keluarga berencana ${ }^{[3]}$. Model CoC diterapkan dalam LTA dimulai pada semester $\mathrm{V}$, dari penelitian sebelumnya yang dilakukan oleh Rawson et.al (2007) dari UK dimana penerapan COC dengan istilah student caseloading dimulai sejak tahun 2004, siswa mendapatkan pengalaman dengan mengikuti perempuan dalam rentang proses kelahiran yang dimulai pada 18 bulan terakhir dari 3 tahun studi dan siswa merupakan pemberi asuhan kebidanan yang utama terhadap perempuan yang menjadi kasusnya ${ }^{[4]}$. Model CoC ini sudah diterapkan lebih awal di luar negeri dan sudah mulai dilakukan mahasiswa pada semester lebih awal.

Mahasiswa dalam melakukan penyusunan LTA dengan model CoC ini ditemukan hasil bahwa mahasiswa dapat menunjukkan ketrampilan dalam memberikan asuhan kebidanan sehingga dapat menjadi bekal mahasiswa nantinya jika lulus dan bekerja. Hal ini seperti Penelitian yang dilakukan oleh Evans et al (2020) kepada mahasiswa kebidanan di salah satu universitas di Australia yang akan lulus, hasil penelitiannya menunjukkan sebagian besar mahasiswa bercita cita untuk bekerja dengan model CoC karena mereka akan mendapatkan kepuasan kerja dengan memberikan perawatan yang berkelanjutan bagi wanita, merawat wanita dengan sepenuhnya dan mereka dapat membuat keputusan yang mandiri terkait asuhan yang diberikan kepada wanita tersebut ${ }^{[5]}$.

Hasil penelitian ini menyebutkan bahwa mahasiswa mengalami kesulitan dalam proses penyusunan proposal, pencarian subjek dan dalam pemberian asuhan kepada klien tidak bisa sepenuhnya terlibat dikarenakan pada mahasiswa masih harus mengikuti kegiatan praktik klinik kebidanan. Kesulitan ini juga dialami oleh mahasiswa kebidanan di salah satu perguruan tinggi di Australia yang dilaporkan dalam penelitian yang dilakukan oleh Gray et.al (2013), dalam penelitian ini mahasiswa dapat belajar dari pengalaman melakukan pendampingan dengan model CoC pada klien, namun mahasiswa mendapatkan kendala yaitu tentang perekrutan perempuan yang akan digunakan sebagai klien dan mahasiswa kesulitan menemukan waktu untuk sepenuhnya terlibat dalam asuhan dengan model $\mathrm{CoC}^{[6]}$.

Klien dalam hal ini adalah ibu atau perempuan dan bayinya yang mendapatkan asuhan kehamilan, persalinan, nifas , bayi baru lahir dan $\mathrm{KB}$ mengatakan puas dan senang dengan adanya pendampingan yang dilakukan oleh mahasiswa Prodi D III Kebidanan FK UNS karena klien memperoleh ilmu dan keterampilan baru serta merasa nyaman dengan adanya pendampingan dari mahasiswa. Penelitian tentang pengalaman perempuan sebagai partisipan dalam proyek CoC dilakukan oleh Hildingsson et al (2020), penelitian ini dilakukan pada 226 wanita di Swedia, mereka mendapatkan pendampingan selama hamil dan bersalin oleh bidan yang dikenalnya, mereka didampingi sejak pertengahan kehamilan hingga dua minggu pasca persalinan. Hasil penelitian menunjukkan bahwa wanita yang menerima perawatan dari bidan yang dikenal dalam persalinan lebih cenderung memiliki pengalaman kelahiran yang positif sehingga risiko mengalami baby blues syndrom sangat rendah ${ }^{[7]}$. Penelitian lain juga dilakukan oleh Tickle et al (2013) yang menguraikan tentang pengalaman wanita (perempuan) hamil yang telah dirawat atau didampingi oleh mahasiswa bidan dengan metode CoC. Hasil penelitian menunjukkan wanita hamil tersebut sangat puas dengan adanya pendampingan yang dilakukan oleh mahasiswa bidan yang memberikan perawatan secara berkesinambungan dan sebagian besar wanita memiliki 
hubungan yang positif dengan mahasiswa kebidanan yang dapat meningkatkan pengalaman melahirkan yang baik bagi mereka ${ }^{[8]}$.

Pembimbing I yang merupakan dosen dari Prodi D III Kebidanan FK UNS memberikan masukan melalui wawancara yang dilakukan oleh peneliti, yaitu model CoC ini lebih baik juga digunakan pada pembelajaran praktik klinik dengan tujuan agar mahasiswa menjadi lebih trampil dalam memberikan asuhan. Penggunaan model $\mathrm{CoC}$ untuk pembelajaran lain seperti penelitian yang dilakukan oleh Cummins et al (2018) yang mengembangkan model konseptual yang memungkinkan bidan lulusan baru dapat bekerja dengan model CoC. Model konseptual tersebut adalah mahasiswa bidan mencari dan melakukan pengalaman $\mathrm{CoC}$, yang salah satunya melalui pembelajaran praktik $^{[9]}$. Peneliti lain, Yanti (2015) yang dilatarbelakangi oleh adanya filosofi pendidikan kebidanan berdasarkan pada model perawatan (asuhan) yang berpusat pada perempuan (CoC). CoC merupakan bagian integral dari konsep asuhan yang berpusat pada perempuan dan dasar dari asuhan kebidanan. Penelitian ini membagi subjek penelitian menjadi dua kelompok, satu kelompok sebagai kelompok eksperimen yaitu kelompok mahasiswa yang mendapat perlakuan model PKK-CoC dan kelompok control dengan model target khusus. Hasilnya implementasi model pembelajaran klinik kebidanan CoC terbukti dapat meningkatkan pemahaman terhadap filosofi asuhan kebidanan women centred care lebih baik pada kelompok perlakuan dibandingkan pada kelompok kontrol target khusus, dengan demikian dapat meningkatkan kesehatan perempuan secara keseluruhan. Serta pada implementasi model pembelajaran klinik $\mathrm{CoC}$, terdapat peningkatan perhatian bidan dalam membimbing siswa dibanding pada model target khusus. Selain itu ada peningkatan kepuasan perempuan sebagai mitra belajar siswa terhadap asuhan kebidanan yang diberikan oleh siswa pada implementasi model pembelajaran klinik $\mathrm{CoC}$ dibanding model target kasus ${ }^{[10]}$.

Penelitian juga dilakukan di program pendidikan kebidanan di Australia oleh Gamble et al (2020) yang bertujuan untuk mengetahui keunggulan dari pelaksanaan CoC sebagai pengalaman yang diberikan kepada mahasiswa. Hasil penelitian menunjukkan bahwa pengalaman menggunakan model $\mathrm{CoC}$ ini dalam pembelajaran menunjukkan adanya hubungan yang saling mendukung dan merawat antara perempuan (klien) dan mahasiswa kebidanan, menumbuhkan kepercayaan klinis antara perempuan dan mahasiswa, serta mempengaruhi tujuan karir dari mahasiswa. Implikasi dan rekomendasi dari hasil penelitian ini yaitu diperlukan standar pendidikan yang mengutamakan pengalaman melakukan CoC sebagai model pembelajaran klinik $^{[11]}$.

Penelitian lain yang relevan yang pernah dilakukan adalah oleh Haq (2016) dengan judul Pengaruh Program OSOC (One Student One Client) Terhadap Pengetahuan dan Ketrampilan Mahasiswa Bidan dalam memberikan asuhan kebidanan. Hasil perbedaan pengetahuan mahasiswa bidan secara signifikan p 0,000 yaitu kelompok perlakuan lebih tinggi $(23,96)$ dibandingkan kelompok kontrol $(22,97)$ setelah praktik klinik dan ada perbedaan keterampilan mahasiswa bidan secara signifikan p 0,048 yaitu kelompok perlakuan lebih tinggi $(86,84)$ dibandingkan kelompok kontrol $(84,71)$ setelah praktik klinik. Simpulan dari Program OSOC berpengaruh terhadap pengetahuan dan keterampilan mahasiswa bidan dalam memberikan asuhan kebidanan. Saran agar Program OSOC dengan konsep metode pembelajaran Continuity of Care dapat dijadikan sebagai model pembelajaran klinik di Institusi Pendidikan Kebidanan dalam upaya meningkatkan pengetahuan 
dan keterampilan mahasiswa bidan dalam memberikan asuhan kebidanan dan kurikulum pembelajaran klinik yang sejalan dengan filosofi asuhan kebidanan yang mendukung profesional behavior $^{[12]}$.

Pembimbing II yang merupakan pembimbing dari lahan juga menyampaikan bahwa mahasiswa Prodi D III Kebidanan UNS perlu diberikan pengalaman yang banyak dengan model CoC sehingga nantinya di dunia kerja mahasiswa ini dapat menerapkan model tersebut dalam memberikan asuhan. Penelitian yang dilakukan Browne et al (2014) menyampaikan bahwa stakeholder membutuhkan bidan yang dalam dirinya memiliki filosofi asuhan kebidanan berkelanjutan yang berpusat pada perempuan dan bidan yang telah memiliki pengalaman dengan model $\mathrm{CoC}$ sebelumnya ${ }^{[13]}$.

\section{Simpulan}

\section{KESIMPULAN}

Hasil analisa pelaksanaan CoC dari penelitian yang telah dilakukan adalah pertama Prodi D III Kebidanan FK UNS telah melakukan model $\mathrm{CoC}$ dalam penyusunan LTA, kedua : mahasiswa dapat meningkat kemampuan dan kompetensinya dengan adanya pemberian asuhan langsung dan berkelanjutan kepada klien melalui model CoC, ketiga : klien sebagai subjek model pembelajaran $\mathrm{CoC}$ puas dan senang dengan pendampingan yang dilakukan oleh mahasiswa, keempat : model CoC yang telah dilaksanakan di Prodi D III Kebidanan FK UNS dapat dikembangkan sebagai model pembelajaran yang lain, sehingga dapat meningkatkan ketampilan mahasiswa dan lulusan.

\section{Saran}

1. Bagi mahasiswa

Bagi mahasiswa diharapkan lebih aktif dalam melakukan pendampingan kepada klien karena akan memberikan pengala- man yang positif baik bagi mahasiswa sendiri maupun klien

2. Bagi institusi pendidikan

Bagi institusi pendidikan diharapkan dapat mengaplikasikan model $\mathrm{CoC}$ dalam pembelajaran praktik

3. Bagi peneliti selanjutnya Bagi peneliti selanjutnya dapat melakukan penelitian yang lebih mendalam tentang penerapan model $\mathrm{CoC}$ dalam pembelajaran kebidanan karena melihat kebermanfaatan dari model $\mathrm{CoC}$ ini.

\section{DAFTAR PUSTAKA}

1. Diana, S. 2017. Model Asuhan Kebidanan Continuity of Care. Surakarta : CV Kekata Group.

2. Glover, P and Sweet L. 2009. An Exploration of the Midwifery Continuity of Care Program at One Australian University as a Symbiotic Clinical Education Model. Nurse Education Today, Volume 33, Issue 3, March 2013, pages 262-67. DOI: 10.1016/j.nedt.2011.11.020

3. Homer, C. S. E.,et al. 2014. The Projected Effect of Scaling Up Midwifery. Lancet, 384, pages 1146-57. http://doi.org/10.1016/S0140-

6736(14)60790-X

4. Rawnson, S, et. al. 2007. Student Midwife Caseloading-a New Approach to Midwifery Education. British Journal of Midwifery, Aug 2008, Vol 16, Issue 8, $\mathrm{p}$ 499-502.DOI 10.12968/bjom.2008.16.8.30782.

5. Evans, J, et al. 2020. The Future in Their Hands : Graduating Student Midwives' Plans, Job Satisfaction and the Desire to Work in Midwifery Continuity of Care. 
Women and Birth, Volume 33, Issue 1, pages e59-e66. https://doi.org/10.1016/j.wombi.2018.11. 011.

6. Gray, J, et al. 2013. Students' Perceptions of the Follow-Through Experience in 3 Year Bachelor of Midwifery Programmes in Australia. Midwifery, Volume 29, Issue 4, pages 400-06.

https://doi.org/10.1016/j.midw.2012.07.0 15.

7. Hildingsson, I., Annika, K., Brigitta, L. 2020. Childbirth Experience in Women Participating in a Continuity of Care Project. Women and Birth. https://doi.org/10.1016/j.wombi.2020.04. 010.

8. Tickle, N., et al. 2016. Women's Experiences of Having a Bachelor of Midwifery Student Provide Continuity of Care. Women and Birth, Volume 29, Issue 3, Pages 245-51. https://doi.org/10.1016/j.wombi.2015.11. $\underline{002}$.

9. Cummins, A.L., Christine, C., Caroline, S. E.H. 2018. Enabling New Graduate Midwives to Work in Midwifery Continuity of Care Models : A Conceptual Model for Implementation. Women and Birth Journal, Volume 31. https://doi.org/10.1016/j.wombi.2017.11. $\underline{007}$
10. Yanti, 2015. Students' understanding of "Women-Centred Care Philosophy" in midwifery care through Continuity of Care $(\mathrm{CoC})$ learning model: a quasiexperimental study. BMC Nurs. 14, 22. doi:10.1186/s12912-015-0072-z.

11. Gamble, J, et al. 2020. Acknowledging the Primacy of Continuity of Care Experiences in Midwifery Education. Women and Birth., Volume 33, Issue 2, Pages

111-8. https://doi.org/10.1016/j.wombi.2019.09. 002.

12. Haq, S. 2016. Pengaruh Program OSOC (One Student One Client) Terhadap Pengetahuan dan Ketrampilan Mahasiswa Bidan dalam Memberikan Asuhan Kebidanan. Tesis. Universitas Aisyiah Yogyakarta. URL http://digilib.unisayogya.ac.id/2398/1/Na skah\%20publikasi fela\%20fastabiq\%20 sofia\%20haq\%20\%28201420102015\%2 9.pdf

13. Browne, J, et 1. 2014. "Continuity of Care" Experiences in Midwifery Education : Perspectives From Diverse Stakeholders. Nurse Education in Practice, Volume 14, Issue 5, Pages 5738.

https://doi.org/10.1016/j.nepr.2014.01.01 4. 